\title{
FECAL CONTAMINATION OF GROUNDWATER IN A SMALL RURAL DRYLAND WATERSHED IN CENTRAL CHILE
}

\author{
Mariela Valenzuela ${ }^{*}$, Bernardo Lagos ${ }^{2}$, Marcelino Claret ${ }^{3}$, María A. Mondaca ${ }^{4}$, Claudio Pérez $^{3}$, and \\ Oscar Parra1.
}

\begin{abstract}
Research on microbiological groundwater quality was conducted in Chile in a rural watershed that has almost no other water source. Forty-two wells were randomly selected and levels of indicator bacteria - total coliforms (TC), fecal coliforms (FC), and fecal streptococci (FS) - were repeatedly measured during the four seasons of 2005. The aim of this study was to characterize microbiological groundwater quality, relate indicator levels to certain watershed features and management characteristics which are likely to affect water quality. The dynamics of seasonal temporal contamination was determined with statistical analyses of indicator organism concentrations. Nonparametric tests were used to analyze relationships between bacterial indicators in well water and other variables. TC, FC, and FS were found in all samples indicating the wells had been contaminated with human and animal fecal material. The frequency distribution of microorganisms fitted a logistic distribution. The concentrations appeared to be temporal and levels varied between seasons with higher concentrations in winter. The cause of contamination could be linked to the easy access of domestic animals to the wells and to the permeable well casing material. Local precipitation runoff directly influenced the bacterial concentrations found in the wells.
\end{abstract}

Key words: biological contamination, bacteria, water quality, environmental pollution.

\section{INTRODUCTION}

Water quality is a key environmental issue involving natural watershed resources and local rural communities. The major environmental pressures have an impact on the quantity and quality of groundwater resources (Danielopol et al., 2003) which are generally perceived as being less vulnerable to contamination than surface water given the natural filtering ability of the subsurface. Although most groundwater is still thought to be free of diseasecausing microorganisms, many systems are unprotected and contamination events could eventually occur because private groundwater wells are rarely, if ever, monitored.

\footnotetext{
${ }^{1}$ Universidad de Concepción, Centro de Ciencias Ambientales EULA, Casilla 160-C, Concepción, Chile.

*Corresponding author (marvalenz@udec.cl).

${ }^{2}$ Universidad de Concepción, Facultad de Ciencias Físicas y Matemáticas, Av. Esteban Iturra s/n - Barrio Universitario, Concepción, Chile.

${ }^{3}$ Instituto de Investigaciones Agropecuarias, Centro Regional de Investigación Quilamapu, Av. Vicente Méndez 515, Chillán, Chile.

${ }^{4}$ Universidad de Concepción, Facultad de Ciencias Biológicas, Casilla 160-C, Concepción, Chile.

Received: 03 January 2008.

Accepted: 29 May 2008.
}

The risk of contaminated water for people was manifested in Lake Erie, Ohio, USA in 2004 when 1450 people became ill because of a pathogen in the well water (Fong et al., 2007). Furthermore, an estimated 750000 to 5.9 million people are sick every year as a result of contaminated groundwater in the USA (Macler and Merkle, 2000).

One of the most frequent types of contamination in rural areas is fecal pollution from different sources, most frequently livestock and inadequate on-site human waste disposal systems (Conboy and Goss, 2001; Barnes and Gordon, 2004). The size and shape of pathogenic microorganisms, their surface density properties, and biological activities set them apart from other contaminants that are transported in surface and subsurface water environments (Pachepsky et al., 2006). Concentrations of microbiological contamination indicator organisms observed in groundwater are a function of the contamination sources active at that moment (SoloGabriele et al., 2000).

Microbiological contamination is dispersed, sporadic, and influenced by a range of interacting environmental factors such as the watershed's physical characteristics, climatic conditions, and agricultural management practices. Since the largest numbers of fecal coliforms and fecal streptococci are always present in manure 
(Chadwick and Chen, 2002), then the presence of either of these microbes in a well water sample is strong evidence of fecal contamination. One of the difficulties in tackling this problem is the fact that contamination is likely to come from various possible point and nonpoint sources (Mahler et al., 2000), thus obscuring its origins. It is important to detect fecal contamination in groundwater, especially if there are no pre-consumption water treatment systems (Atherholt et al., 2003). This is the case in some rural dryland areas of Chile where farmers obtain small amounts of water from private wells and face serious water supply problems for both human consumption and agricultural activities.

Improving the quality of groundwater resources offers an important economic opportunity for the gradual improvement of the quality of life in rural dryland communities. In order to develop strategies to diminish or eliminate microbiological contamination in groundwater wells, it is first necessary to assess the variability in its concentrations, and the relative importance of different factors affecting pollution.

The variability of microorganism concentrations in Chilean groundwater and the factors affecting them are not well-known at present. As rural communities continue to rely on shallow groundwater, it is important to improve the state of knowledge about the quality of this resource. To assess the presence of fecal contamination in a rural watershed, a study was undertaken to typify the quality of microbiological groundwater, describe its seasonal pattern, and look for probable characteristics exerting an influence on the quality of groundwater.

\section{MATERIALS AND METHODS}

The small rural Estero San José (ESJ) watershed (10.8 $\mathrm{km}^{2}$ ) is located in the Bío-Bío Region, Chile (Figure 1). The catchment area is sparsely inhabited by families dedicated to traditional agriculture. The ESJ watershed is characterized by a Mediterranean climate with a long dry season leading to water shortages and a short wet season.

The watershed soils have low permeability and capacity to provide underground water. Moisture accumulation in the watershed takes place between April and June. The major runoff period of the year is from July to October when the ground is saturated and almost all the precipitation that falls in the watershed runs off. Precipitation is scarce between November and March, with practically no base flow in the watershed. Farmers obtain small amounts of water from private wells. On the average, these are $7.0 \mathrm{~m}$ deep and yield a median of 1.1 $\mathrm{L} \mathrm{min}^{-1}$. Groundwater is used as drinking water, for other domestic purposes, orchards, gardens, greenhouses, and livestock production. Agricultural production in the area
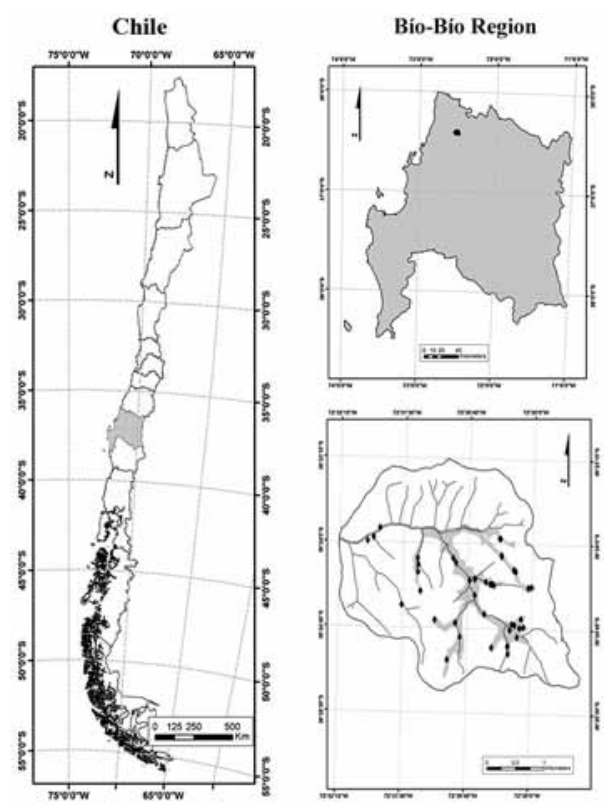

\section{Figure 1. Location of the Estero San José Watershed and sampling sites.}

is mostly wheat (Triticum aestivum L.) and lentils (Lens culinaris Medik.). The density of domestic animals is low.

A 10-month monitoring study was undertaken. Fortytwo wells were chosen with the Stratified Random Sample (Murray, 2002) and site-location data were determined with global positioning system units (Garmin 12XL, Garmin International Inc., Kansas, USA). Water pH was measured in the field with Hanna Instruments ${ }^{\circledR}$ HI9025, whereas electrical conductivity (EC) and temperature were measured with Hanna Instruments ${ }^{\circledR}$ HI9835. The sampling periods were defined in accordance with the precipitation regime and variations in the hydrologic levels in the wells. Based on these criteria, four sampling seasons were established (March, June, September, and December).

Water samples were analyzed for total coliforms (TC), fecal coliforms (FC), and fecal streptococci (FS). Although TC is widespread in the environment, it was included in order to meet the Chilean standard requirement (NCh 409. Of 70). Aseptic sample collections were taken in sterilized flasks. Samples were held at $5{ }^{\circ} \mathrm{C}$ after being collected and for no more than $6 \mathrm{~h}$ until reaching the laboratory. Results were expressed in colony forming units (CFU) per $100 \mathrm{~mL}$. TC, FC, and FS concentrations were analyzed with a membrane filtration technique following standard methods (Clesceri et al., 1998). Aliquots (100, 10 , and $1 \mathrm{~mL}$ ) of each water sample were filtered through a $0.45 \mu$ Millipore membrane filter. All samples were tested in triplicate. Results were reported as CFU 100 
$\mathrm{mL}^{-1}$. Samples that were overgrown were considered to contain > $1000 \mathrm{CFU} 100 \mathrm{~mL}^{-1}$. Colonies forming a green metallic sheen were counted as TC on m-Endo agar (Difco ${ }^{\circledR}$, Detroit, MI, USA). To count FC, filters were placed on Petri dishes containing m-FC agar (Difco ${ }^{\circledR}$, Detroit, MI, USA) which gave the selected colonies a blue color, whereas the selective FS count was carried out by incubating the filters in $\mathrm{m}$-Enterococcus agar (Difco ${ }^{\circledR}$, Detroit, MI, USA). Water sample analyses were performed in the microbiology laboratory of the Centro de Ciencias Ambientales (EULA) at the Universidad de Concepción.

Count data analyses were performed with STATISTICA ${ }^{\text {TM }}$ StatSoft 6.0. The median was used rather than the mean to analyze the microbiological data because it basically eliminates extreme values (Smith et al., 1996).

Results for TC, FC, and FS obtained in the four seasons were analyzed by looking for spatial correlations with spatial S-PLUS software using Geary's and Moran's Index (Cai and Wang, 2006). Statistical analyses were conducted to determine the relationship between bacterial concentrations and $\mathrm{pH}$, electrical conductivity, temperature, and factors expected affecting concentrations or associated with the presence of indicator bacteria. These variables were treated as binomial categorical data. To further the analysis, the variables were transformed from continuous to categorical. Data included different land use activities (prairie, gardens, orchards, bare soil) within the proximity of the monitoring well $(\mathrm{ca} .10 \mathrm{~m}$ radius); well condition (good, average, and poor); well location (highlands or lowlands); well cover (wood or cement); border height (to 15, 50, and $100 \mathrm{~cm}$ ); casing (cement or brick); slope (to 15\%, between 15\% and 60\%), latrine characteristics (location uphill or downhill from the well, casing); animal access in the vicinity of the well; type of animal (horses, pigs, sheep, poultry, cattle, dogs), and well-to-latrine distance (to $30 \mathrm{~m}$, to $80 \mathrm{~m}$ ). Parameters such as soil and geology were assumed to be constant because of the small differences detected at each sample site. Data were analyzed statistically by nonparametric Mann-Whitney rank-sum and Kolmogorov-Smirnov tests (Rohatgi, 1984) to determine significant differences in mean concentrations and indicator distribution found in well groups presenting specific characteristics. Factors were ordered dichotomously. Rainfall data were collected as an additional factor likely to exert an influence on microbiological quality. The environmental variables were selected because of their expected impact on the numbers of microorganisms detected in the samples.

\section{RESULTS AND DISCUSSION}

Groundwater indicator bacteria concentrations exceeded Chilean water quality regulations in all samples (NCh 409 Of. 70). The three indicators had a detection rate of $100 \%$, finding at least 1 CFU 100 $\mathrm{mL}^{-1}$ in all tested samples. These concentrations indicated degraded groundwater quality. The existence of both FC and FS provided strong evidence of fecal contamination (Atherholt et al., 2003). The presence of indicators in all four sampling seasons denoted frequent, if not continuous, fecal contamination in the ESJ watershed. There seemed to be a permanent source of fecal bacteria regularly entering the wells. Microbial data (Table 1) revealed marked variations throughout the year.

The most frequent indicator was TC. Seasonal variations in the microbial quality of water were evident, with peaks in winter for TC, FC, and FS. Variations in FC were less dramatic than in FS. Median concentrations of TC, FC, and FS increased in June (as compared to March), decreased in September, and increased again in December (Figure 2). This last increase can be attributed to higher demands on the wells during the later part of the year, combined with minimal water yields. Environmental persistence or growth of bacterial indicators during the summer months could confound the interpretation of baseline dynamics (Shanks et al., 2006).

The wells exhibited a high proportion of low counts and a small number of very high counts that exerted a significant influence on the median. Indeed, bacterial indicators from natural sources do not usually occur in elevated concentrations since they come from disperse sources such as waste of warm-blooded animals (Ortiz, 2004). During transport and after retention in the soil, microorganisms are affected by environmental conditions

Table 1. Median and range of indicator bacteria concentrations in the four sampled months (CFU $\left.100 \mathrm{~mL}^{-1}\right)$.

\begin{tabular}{|c|c|c|c|c|c|c|c|}
\hline \multirow{2}{*}{$\begin{array}{l}\text { Sampled } \\
\text { month }\end{array}$} & \multirow{2}{*}{$\begin{array}{c}\mathbf{N}^{\mathbf{0}} \\
\text { samples }\end{array}$} & \multicolumn{2}{|c|}{$\begin{array}{l}\text { Total } \\
\text { coliforms }\end{array}$} & \multicolumn{2}{|c|}{$\begin{array}{l}\text { Bacterial indicator } \\
\text { Fecal coliforms }\end{array}$} & \multicolumn{2}{|c|}{$\begin{array}{c}\text { Fecal } \\
\text { streptococci }\end{array}$} \\
\hline & & Median & Range & Median & Range & Median & Range \\
\hline March & 41 & 257 & $16-4.71 \times 10^{3}$ & 27 & $1-1.16 \times 10^{3}$ & 196 & $9-1.12 \times 10^{3}$ \\
\hline June & 41 & 501 & $14-5.00 \times 10^{3}$ & 190 & $1-5.80 \times 10^{3}$ & 290 & $20-1.17 \times 10^{3}$ \\
\hline September & 42 & 255 & $11-1.06 \times 10^{4}$ & 10 & $1-3.00 \times 10^{2}$ & 67 & $9-1.28 \times 10^{3}$ \\
\hline December & 39 & 440 & $22-3.60 \times 10^{3}$ & 53 & $1-1.38 \times 10^{3}$ & 120 & $5-1.10 \times 10^{3}$ \\
\hline
\end{tabular}


such as nutrient availability and predation (Pachepsky et al., 2006). Moreover, traditional monitoring and research programs quantify the microorganism concentrations in samples using standard methods. These methods are designed to target public health and do not completely measure either clumped organisms or those associated with particles, and may not fully specify organism concentrations (Borst and Selvakumar, 2003).

Indicator concentration data fit a logistic distribution, showing a parallel evolution in the distribution of FC and FS (Figures 3, 4, 5). A descriptive criterion was chosen for this distribution.

Statistical analyses showed that FC was better correlated with TC in March, June, and December, and with FS in September. In June (winter), the three indicators showed the highest correlation. FC and TC were highly correlated. Correlation analyses revealed a strong, significant, and positive correlation between TC and FC in June (Table 2). A strong relationship between two indicators may provide some evidence that both indicators originate from the same or similar contamination sources (Francy et al., 2000). Correlations between indicators, without considering the season, were very low $(r=0.35$

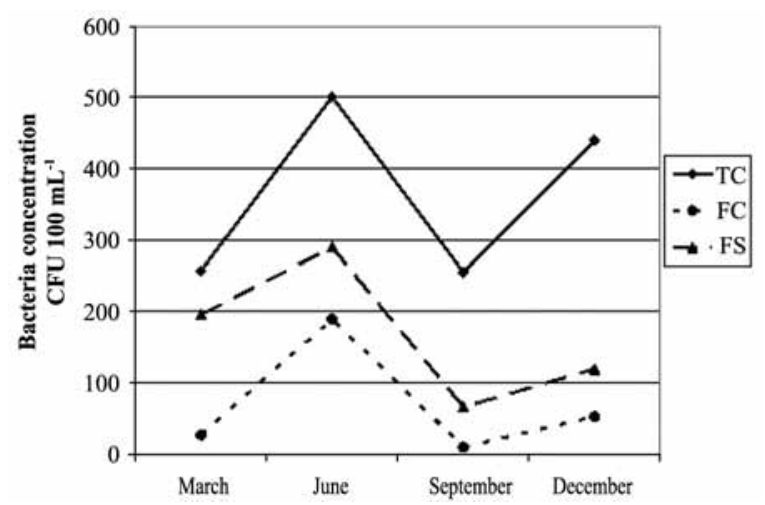

CFU: Colony Forming Units; TC: Total Coliforms; FC: Fecal Coliforms; FS: Fecal Streptococci.

Figure 2. Median concentrations of indicator bacteria.

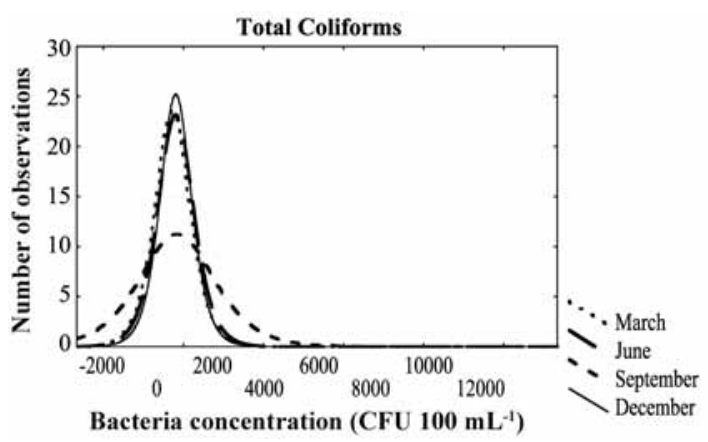

Figure 3. Logistic distribution of TC (Total Coliforms). between TC and FC, $\mathrm{r}=0.34$ between FC and FS, and $\mathrm{r}$ $=0.21$ between TC and FS, $\mathrm{p}<0.05$ ). Strong correlations between indicators were obtained only when the analyses considered the season. Analysis of the annual pattern showed almost no correlations. This confirmed the importance of carrying out seasonal analyses.

By comparing indicator medians in different seasons (Kruskal-Wallis test for comparing medians), it was possible to obtain results for $\mathrm{FC}$ (p-value $=2.95 \times$ $10^{9}$ ) which infer that seasonal medians were not equal, although FC did not change drastically with the seasons. There were differences (with a significance level of 5\%) between the medians of: March/June, March/ September, June/September, and September/December. FS had a p-value $=7.95 \times 10^{7}$. Differences had the same significance level between the medians of: March/ September, June/September, and June/December. The significant differences observed between the median concentrations of June with respect to September and December for FC and FS showed a temporal change. Median concentrations of TC did not differ significantly between seasons. Persistence of bacteria in the aquatic environment depends on various parameters, especially on the existing nutrients and temperatures (Leclerc et al., 2002). The prevalence of FS, which die off more rapidly in the environment than other bacterial indicators, shows either relatively recent contamination of a source by fecal

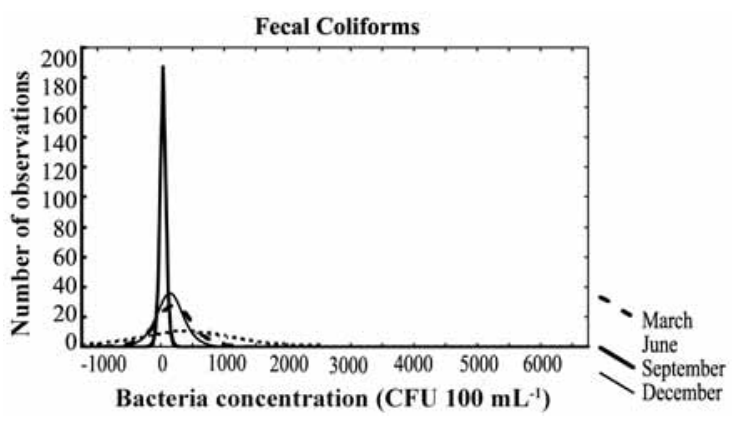

Figure 4. Logistic distribution of FC (Fecal Coliforms).

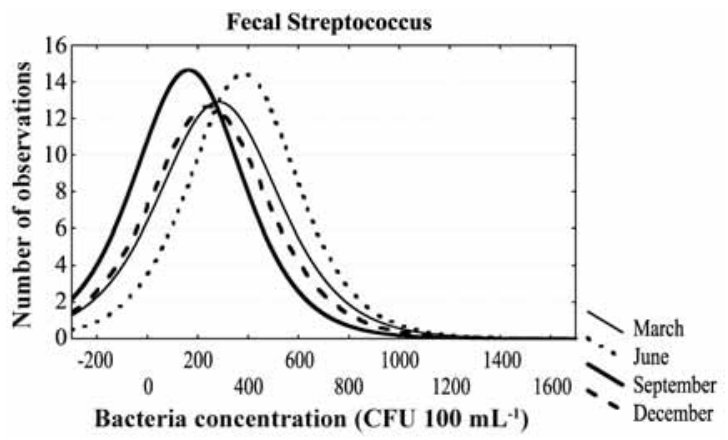

Figure 5. Logistic distribution of FS (Fecal Streptococci). 
Table 2. Correlation coefficients (r) between different indicator organism concentrations.

\begin{tabular}{|c|c|c|c|c|c|c|c|c|c|c|c|c|}
\hline \multirow[b]{3}{*}{ Organism } & \multicolumn{12}{|c|}{ Sample month } \\
\hline & \multicolumn{3}{|c|}{ March } & \multicolumn{3}{|c|}{ June } & \multicolumn{3}{|c|}{ September } & \multicolumn{3}{|c|}{ December } \\
\hline & TC & FC & FS & TC & FC & FS & TC & FC & FS & TC & FC & FS \\
\hline TC & 1 & 0.26 & 0.28 & 1 & $0.91^{*}$ & $0.60 *$ & 1 & 0.23 & $0.41 * *$ & 1 & $0.40 * *$ & -0.06 \\
\hline FC & & 1 & 0.11 & & 1 & $0.53^{*}$ & & 1 & 0.24 & & 1 & 0.12 \\
\hline FS & & & 1 & & & 1 & & & 1 & & & 1 \\
\hline
\end{tabular}

${ }^{*} \mathrm{p}<0.001 .{ }^{* *} \mathrm{p}<0.05$. TC: Total coliforms. FC: Fecal coliforms. FS: Fecal streptococci.

material or a very high level of contamination possibly associated with organic matter (Conboy and Goss, 2001); the latter could have been the case in September. FC was more persistent in freshwater than FS (Anderson et al., 2005). Nevertheless, in an experiment of some treatments in simulated groundwater environments by Conboy and Goss (2001), FS was able to survive for over $140 \mathrm{~d}$.

Concentrations of TC, FC, and FS were not correlated with well temperature, conductivity, and $\mathrm{pH}(\mathrm{p}<0.001)$. Rainfall measured over the sampling period was $23.6 \mathrm{~mm}$ until March, $447.7 \mathrm{~mm}$ between March and June, 302.5 $\mathrm{mm}$ between June and September, and $59.9 \mathrm{~mm}$ between September and December (Figure 6).

The highest rainfall was recorded between May and July. FC and FS median concentrations varied over time and showed a pattern similar to that of rainfall. However, FS were more affected by rainfall than FC, although the variation patterns of $\mathrm{FC}$ were highly influenced by two extreme concentrations. Correlation coefficients between indicators and rainfall showed a significant relationship with FC $(r=0.84)$ and FS $(r=0.81)$. This relationship was weak for TC $(r=0.23)$ and not coupled with other factors. The high temporal variance in the collected data means that precipitation can exert an influence by providing transport energy for the potential sources. The median demonstrated that microbial water quality changes following a rainfall runoff pattern for microbial source inputs, with a marked annual cycle (Figure 6). Results revealed a strong association between bacterial concentrations in groundwater wells and rainfall through elevated concentrations in samples taken after precipitation. It can be assumed that the higher concentrations recorded in June are partly attributable to the fact that it is the wettest month of the year. These correlations suggest that bacteria were largely associated with suspended particulate materials and transported by runoff, since some coliforms in runoff are associated with particles (George et al., 2004). Characteristics of the initial fecal material deposition site on the soil surface influence the infiltration, runoff, and retention rate of the microorganisms in the feces (Ferguson et al., 2003). Soil surrounding wells was eroded at almost all the sites, thereby preventing interaction between bacteria that could be transported by runoff and allowing them to eventually reach the well.

Moreover, no spatial correlations were found according to Geary's and Moran's Index. Neighboring wells were hydrologically independent. Spatial variability in the concentrations of TC, FC, and FS was not significant (Kolmogorov-Smirnov test, $\mathrm{p}<0.05$ ) between sampling sites in the highlands and lowlands of the watershed. Fecal contamination due to surface runoff implied that the phenomenon is highly responsive to rainfall intensity and duration, and will display a high degree of temporal variability. The fact that there is no significant difference between concentrations of indicators in highlands and lowlands suggests that local runoff produced the contamination rather than a landscape level phenomenon.

The analysis of the relationship between bacterial indicator levels and environmental characteristics presents several statistical challenges. Due to the complex nature of FC destination and transport, empirical methods such as regression models are unable to build up reliable load-concentration relationships (Bai and Lung, 2006). However, factors (Table 3) were recorded which were expected to affect concentrations or be associated with the presence of indicator bacteria since these offer preliminary insight into the causes of well contamination.

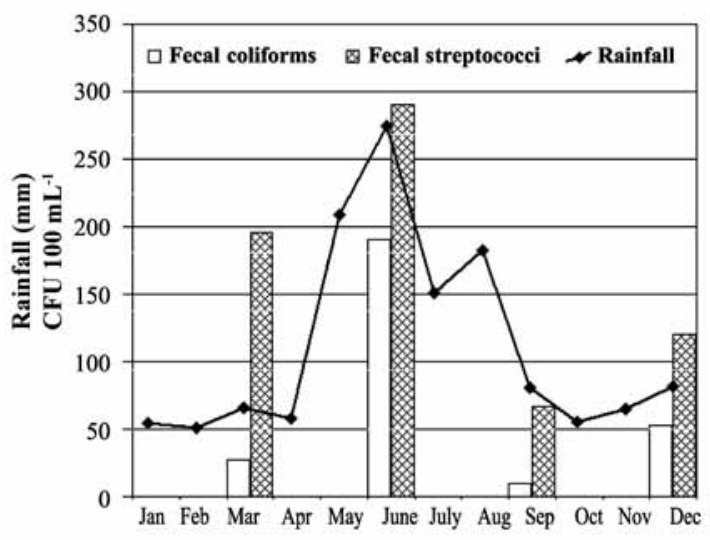

Figure 6. Rainfall and seasonal variability of indicator bacteria concentrations. 
Table 3. Landscape and management factors expected to affect concentrations or be associated with the presence of indicator bacteria.

\begin{tabular}{|c|c|c|c|c|c|c|c|c|c|c|c|}
\hline Well & $\begin{array}{l}\text { Land } \\
\text { use }\end{array}$ & Slope & $\mathbf{A A}$ & $\begin{array}{c}\text { Animal } \\
\text { type }\end{array}$ & $\begin{array}{c}\text { Well } \\
\text { condition }\end{array}$ & $\begin{array}{l}\text { Well } \\
\text { cap }\end{array}$ & $\begin{array}{c}\text { Well } \\
\text { cover }\end{array}$ & $\mathbf{B ~ h}$ & $\mathbf{L U}$ & D & $\begin{array}{c}\mathbf{L} \\
\text { casing }\end{array}$ \\
\hline 1 & Prairie & 5 & Yes & $\mathrm{H}$ & Good & Wood & Cement & 45 & Yes & 85 & Cement \\
\hline 2 & Orchard & 15 & Yes & $\mathrm{Pi}$ & Good & Wood & Cement & 100 & Yes & 11 & Cement \\
\hline 3 & Garden & 5 & No & - & Good & Wood & Brick & 30 & No & 42 & None \\
\hline 4 & Orchard & 5 & Yes & Po & Good & Cement & Cement & 60 & No & 84 & None \\
\hline 5 & Orchard & 9 & No & - & Regular & Cement & Brick & 30 & Yes & 44 & Cement \\
\hline 6 & Prairie & 15 & Yes & S & Regular & Wood & Cement & 30 & No & 40 & None \\
\hline 7 & Prairie & 10 & Yes & S & Poor & Wood & Cement & 40 & No & 52 & None \\
\hline 8 & Bare soil & 26 & No & - & Good & Cement & Cement & 3 & Yes & 70 & None \\
\hline 9 & Orchard & 10 & Yes & Po & Regular & Cement & Cement & 70 & Yes & 28 & None \\
\hline 10 & Orchard & 18 & No & - & Regular & Wood & Cement & 75 & Yes & 83 & None \\
\hline 11 & Orchard & 40 & Yes & Po & Poor & Wood & Cement & 40 & Yes & 62 & Cement \\
\hline 12 & Orchard & 35 & Yes & Po. C & Poor & Wood & Cement & 40 & Yes & 85 & None \\
\hline 13 & Orchard & 35 & Yes & Po & Regular & Cement & Cement & 40 & Yes & 50 & None \\
\hline 14 & Orchard & 40 & Yes & Po, pi & Good & Cement & Cement & 60 & Yes & 62 & Cement \\
\hline 15 & Bare soil & 18 & No & - & Regular & Wood & Cement & 50 & Yes & 82 & None \\
\hline 16 & Prairie & 30 & Yes & Po & Poor & Wood & Brick & 18 & Yes & 120 & None \\
\hline 17 & Bare soil & 45 & Yes & Po, C & Good & Cement & Cement & 40 & No & 86 & None \\
\hline 18 & Prairie & 5 & Yes & Po, C & Good & Cement & Cement & 50 & No & 86 & None \\
\hline 19 & Prairie & 53 & Yes & Po, pi & Regular & Wood & Cement & 5 & Yes & 60 & None \\
\hline 20 & Orchard & 45 & No & - & Good & Cement & Brick & 15 & Yes & 48 & None \\
\hline 21 & Orchard & 25 & No & - & Good & Cement & Brick & 60 & Yes & 43 & None \\
\hline 22 & Bare soil & 5 & Yes & $\mathrm{H}$ & Good & Cement & Cement & 20 & Yes & 70 & None \\
\hline 23 & Orchard & 0 & No & - & Regular & Cement & Brick & 40 & No & 22 & None \\
\hline 24 & Prairie & 18 & No & - & Regular & Cement & Brick & 60 & Yes & 18 & None \\
\hline 25 & Prairie & 15 & Yes & Po, D & Good & Cement & Cement & 70 & Yes & 50 & None \\
\hline 26 & Garden & 10 & Yes & Po & Good & Cement & Cement & 40 & No & 23 & Cement \\
\hline 27 & Orchard & 23 & Yes & $\mathrm{C}$ & Good & Cement & Cement & 60 & Yes & 62 & Cement \\
\hline 28 & Orchard & 4 & Yes & Po & Regular & Wood & Brick & 80 & Yes & 79 & Cement \\
\hline 29 & Orchard & 17 & Yes & Po & Regular & Wood & Cement & 55 & Yes & 80 & Cement \\
\hline 30 & Prairie & 18 & Yes & Po, C & Poor & Wood & Cement & 10 & Yes & 91 & None \\
\hline 31 & Prairie & 40 & Yes & Po, C & Good & Wood & Cement & 50 & Yes & 133 & None \\
\hline 32 & Orchard & 22 & Yes & Po, S & Regular & Wood & Cement & 50 & Yes & 10 & Cement \\
\hline 33 & Orchard & 12 & Yes & Po & Good & Cement & Cement & 20 & Yes & 42 & None \\
\hline 34 & Bare soil & 13 & Yes & $\mathrm{S}$ & Poor & Cement & Cement & 5 & Yes & 54 & None \\
\hline 35 & Garden & 20 & No & - & Good & Wood & Cement & 50 & Yes & 26 & None \\
\hline 36 & Orchard & 15 & Yes & D & Good & Cement & Cement & 60 & Yes & 39 & None \\
\hline 37 & Prairie & 5 & No & - & Good & Cement & Cement & 100 & No & 10 & Cement \\
\hline 38 & Orchard & 18 & Yes & Po & Poor & Wood & Cement & 90 & Yes & 41 & None \\
\hline 39 & Prairie & 35 & No & - & Regular & Cement & Brick & 120 & No & 45 & None \\
\hline 40 & Orchard & 40 & Yes & Po, D & Poor & None & Cement & 45 & Yes & 11 & None \\
\hline 41 & Orchard & 5 & No & - & Poor & None & Cement & 12 & Yes & 63 & None \\
\hline 42 & Orchard & 15 & No & - & Regular & Wood & Cement & 30 & No & 82 & None \\
\hline
\end{tabular}

AA: animal access to the well. Bh: well border height. LU: latrine uphill from the well. D: distance between well and the closest latrine. L casing: latrine casing. Animal type: H: horses, Pi: pigs, Po: poultry, S: sheep, C: cattle, D: dogs. 
The distance between wells and latrines is highly variable, ranging from a minimum of 10 to $133 \mathrm{~m}$. Seventyfour percent of the latrines in the sampled households had brick casing. Hence, they were not sealed. On at least one of the four sampling dates, animals were observed around approximately $67 \%$ of the wells. Table 4 demonstrates that characteristics with $\mathrm{p}<0.052$ were considered to be statistically significant. Statistical analysis of the data showed that five factors are likely to influence the concentration of bacteria in groundwater: animal access close to the wells (specifically pigs and poultry); land use; bricks used for well casing; latrine-to-well distance; and a slope up to $15 \%$. Only two of these factors showed a highly significant $(p<0.01)$ association with the presence of the bacterial indicators: animal access close to the well in June and a latrine-to-well distance of $<80 \mathrm{~m}$ in December.

These results suggest that the most important factors affecting well vulnerability to bacterial contamination were those related to the well itself: construction and site management. In the month when the indicator concentrations are the highest, the factors potentially influencing these levels are animal access (specifically poultry) and well casing. Some wells have a brick casing instead of cement, which does not seal them sufficiently and allows water runoff from the surroundings to enter. Statistically, contamination levels were more closely tied to animal access in the vicinity of wells and the well casing material than to land use or distance between wells and latrines. Livestock grazing practices creates a diffuse source of fecal contamination to watersheds (Tian et al., 2002; Harter et al., 2002). Pathogens from animal feces may enter waterways by direct deposition or as a result of overland runoff containing fecal material deposited in the watershed. The FC:FS ratio as used by (Donderski and Wilk, 2002; Troussellier et al., 2004) showed that the source of indicator bacteria is mostly animal, followed by mixed sources. Considering that a great number of wells have fences to prevent animal access, wildlife cannot be disregarded as a source. Cox et al. (2005) showed that poultry fecal samples have a higher FC concentration (median $1.1 \times 10^{8} \mathrm{CFU} \mathrm{g}^{-1}$ wet wt) than those of other domestic animals (median for adult cattle $1.8 \times 10^{5} \mathrm{CFU} \mathrm{g}^{-1}$ wet wt, pigs $7.1 \times 10^{6} \mathrm{CFU} \mathrm{g}^{-1}$ wet wt, and sheep $6.6 \times 10^{5}$ CFU g ${ }^{-1}$ wet wt). This could explain the significance of poultry access to the wells as a factor affecting indicator counts. Furthermore, Wheeler et al. (2002) demonstrated that Enterococcus faecalis had a limited host range and was found in humans, dogs, and chickens.

Land use in the watershed also affected the extent of fecal contamination, but not as strongly as the other factors described above. A pattern did not emerge in spite of the fact that three different land uses were significant. Latrines appear to have little influence on the presence and level of bacterial indicators, suggesting that latrines can also be a potential source of microbial contamination in groundwater. Other factors not considered in this study may also affect bacterial concentrations in well water.

These data provide new information by relating indicator bacteria loads for certain factors at specific times of the year. The fact that the most significant indicator related to a factor was TC in March and in December, FC in June, and FS in September, suggests that fecal contamination is mostly a winter phenomenon.

Table 4. Factors with significant differences between the means of indicator bacteria concentrations.

\begin{tabular}{lllcl}
\hline Month & \multicolumn{1}{c}{ Indicator } & \multicolumn{1}{c}{ Factor } & P & \multicolumn{1}{c}{ Test } \\
\hline March & Fecal streptococcus & Land use: bare soil & 0.038 & Mann-Whitney \\
March & Total coliforms & Pig access & 0.015 & Mann-Whitney \\
June & Fecal coliforms & Animals close to well & $<0.005$ & Kolmogorov-Smirnov \\
June & Fecal coliforms & Animals close to well & 0.021 & Mann-Whitney \\
June & Fecal coliforms & Poultry access & $<0.05$ & Kolmogorov-Smirnov \\
June & Fecal coliforms & Poultry access & 0.052 & Mann-Whitney \\
September & Fecal streptococcus & Land use: orchard & 0.051 & Mann-Whitney \\
September & Fecal streptococcus & Well casing material (brick) & $<0.05$ & Kolmogorov-Smirnov \\
September & Fecal streptococcus & Well casing material (brick) & 0.041 & Mann-Whitney \\
September & Fecal streptococcus & Latrine-to-well distance $<80 \mathrm{~m}$ & 0.044 & Mann-Whitney \\
December & Fecal streptococcus & Land use: garden & 0.039 & Mann-Whitney \\
December & Fecal streptococcus & Slope $<$ 15\% & 0.041 & Mann-Whitney \\
December & Total coliforms & Well casing material (brick) & $<0.05$ & Kolmogorov-Smirnov \\
December & Total coliforms & Well casing material (brick) & 0.033 & Mann-Whitney \\
December & Total coliforms & Latrine-to-well distance $<80 \mathrm{~m}$ & $<0.05$ & Kolmogorov-Smirnov \\
December & Total coliforms & Latrine-to-well distance $<80 \mathrm{~m}$ & 0.007 & Mann-Whitney \\
\hline
\end{tabular}




\section{CONCLUSIONS}

There is widespread groundwater contamination in the ESJ watershed. The microbiological quality of the sampled wells was impaired with regard to Chilean standards.

A seasonal trend was identified. Concentrations of FC and FS varied over time and showed a pattern similar to rainfall which appeared to exert a local influence on the indicator concentrations. FS were more affected by rainfall than FC.

The lack of a significant difference between wells located uphill and downhill suggests that contamination is not a result of surface runoff from upgradient areas. Our results indicate that one cause of microbial contamination in well water is manure bacteria entering directly through local surface runoff.

There was no spatial correlation between wells, showing that there were no identified groups of wells which maintained certain concentration tendencies.

The present study shows that the analysis of microbial data in combination with basic environmental and management data can provide preliminary insight into the causes of fecal contamination in groundwater. In fact, indicator counts turned out to be significantly related to certain watershed features during specific months. Inherent well site characteristics and its surroundings, as well as rainfall are the main factors that affect groundwater quality in the ESJ watershed.

\section{ACKNOWLEDGEMENTS}

This study was funded in partnership with JICA, Japan International Cooperation Agency.

\section{RESUMEN}

Contaminación fecal en agua subterránea en una pequeña cuenca de secano rural en Chile Central. Se realizó una investigación de la calidad microbiológica de las aguas subterráneas en una cuenca rural chilena. En esta cuenca prácticamente no había otra fuente de agua disponible. En 42 pozos seleccionados al azar, se midieron niveles de bacterias indicadoras en cuatro temporadas distintas durante el año 2005. Las bacterias incluyeron coliformes totales (TC), coliformes fecales (FC) y Estreptococos fecales (FS). El objetivo fue caracterizar la calidad microbiológica del agua subterránea y relacionar los indicadores con ciertas propiedades y el manejo de la cuenca que pueden afectar la calidad del agua. La dinámica temporal de la contaminación fue determinada mediante análisis estadístico de la concentración de organismos indicadores. Las relaciones entre indicadores bacteriales presentes en el agua de los pozos y otras variables fueron analizadas con pruebas no paramétricas. En todas las muestras se detectaron TC, FC y FS, indicando que los pozos han estado contaminados con material fecal de humanos y animales. La distribución de frecuencia de los microorganismos se ajustó a una distribución logística. Las concentraciones muestran una base temporal con niveles variables entre temporadas, con una mayor concentración en invierno. La causa de la contaminación se puede asociar al fácil acceso de los animales domésticos a los pozos, y a su material de revestimiento permeable. La escorrentía local de las precipitaciones mostró tener una influencia directa sobre la concentración de los microorganismos en los pozos y en la concentración de los indicadores bacteriales encontrados en los pozos.

Palabras clave: contaminación biológica, bacteria, calidad del agua, contaminación ambiental.

\section{LITERATURE CITED}

Anderson, K.L., J.E Whitlock, and V.J. Harwood. 2005. Persistence and differential survival of fecal indicator bacteria in subtropical waters and sediments. Appl. Environ. Microbiol. 71:3041-3048.

Atherholt, T., E. Feerst, B. Hovendon, J. Kwak, and J. Rosen. 2003. Evaluation of indicators of fecal contamination in groundwater. J. Am. Water Works Assoc. 95:119-131.

Bai, S., and W-S. Lung. 2006. Three-dimensional modeling of fecal coliform in the tidal basin and Washington channel, Washington, DC. J. Environ. Sci. Health A. Tox. Hazard Subst. Environ. Eng. 41:1327-1346.

Barnes, B., and D.M. Gordon. 2004. Coliform dynamics and the implications for source tracking. Environ. Microbiol. 6:501-509.

Borst, M., and A. Selvakumar. 2003. Particle-associated microorganisms in stormwater runoff. Water Res. 37:215-223.

Cai, X., and D. Wang. 2006. Spatial autocorrelation of topographic index in catchments. J. Hydrol. 328:581591.

Chadwick, D.R., and S. Chen. 2002. Manures. p. 5882. In Haygarth, P., and S. Jarvis (eds.) Agriculture, hydrology and water quality. CABI Publishing. Institute of Grassland and Environmental Research, North Wyke, Devon, UK.

Clesceri, L.S., Greenberg, A.E., and A.D. Eaton (eds.) 1998. Standard methods for the examination of water and wastewater. 20 $0^{\text {th }}$ ed. 1325 p. American Public Health Association (APHA), Washington DC, USA. 
Conboy, M.J., and M.J. Goss. 2001. Identification of an assemblage of indicator organisms to assess timing and source of bacterial contamination in groundwater. Water Air Soil Pollut. 129:101-118.

Cox, P., M. Griffith, M. Angles, D. Deere, and C. Ferguson. 2005. Concentrations of pathogens and indicators in animal feces in the Sydney watershed. Appl. Environ. Microbiol. 71:5929-5934.

Danielopol, D.L., C. Griebler, A. Gunatilaka, and J. Notenboom. 2003. Present state and future prospects for groundwater ecosystems. Environ. Conserv. 30:104-130.

Donderski, W., and I. Wilk. 2002. The sanitary state of water in the river Vistula between Wyszogrod and Torun. Pol. J. Environ. Stud. 11:509-515.

Ferguson, C., A. Husman, N. Altavilla, D. Deere, and N. Ashbolt. 2003. Fate and transport of surface water pathogens in watersheds. Crit. Rev. Environ. Sci. Tecnol. 33:299-361.

Fong, T.-T., L.S. Mansfield, D.L. Wilson, D.J. Schwab, S.L. Molloy, and J.B. Rose. 2007. Massive microbiological groundwater contamination associated with a waterborne outbreak in Lake Erie, South Bass Island, Ohio. Environ. Health Persp. 115:856-863.

Francy, D.S., D.R. Helsel, and R.A. Nally. 2000. Occurrence and distribution of microbiological indicators in groundwater and stream water. Water Environ. Res. 72:152-161.

George, I., A. Anzil, and P. Servais. 2004. Quantification of fecal coliform inputs to aquatic systems through soil leaching. Water Res. 38:611-618.

Harter, T., H. Davis, M.C. Mathews, and R.D. Meyer. 2002. Shallow groundwater quality on dairy farms with irrigated forage crops. J. Contam. Hydrol. 55:287-315.

Leclerc, H., L. Schwartzbrod, and E. Dei-Cas. 2002. Microbial agents associated with waterborne diseases. Crit. Rev. Microbiol. 28:371-409.

Macler, B.A., and J.C. Merkle. 2000. Current knowledge on groundwater microbial pathogens and their control. Hydrogeol. J. 8:29-40.

Mahler, B.J., J.-C. Personné, G.F. Lods, and C. Drogue. 2000. Transport of free and particulate- associated bacteria in karst. J. Hydrol. 238:179-193.
Murray, C.J. 2002. Sampling and data analysis for environmental microbiology. p. 166-178. In Hurst, C.J., R.L. Crawford, G.R. Knudsen, M.J. McInerney, and L.D. Stetzenbach (eds.) Manual of environmental microbiology. $2^{\text {nd }}$ ed. ASM Press, Washington D.C., USA.

Ortiz, R. 2004. Ground-water quality of alluvial and sedimentary-rock aquifers in the vicinity of Fairplay and Alma, Park County, Colorado, September-October 2002. USGS Fact Sheet 2004-3065. US Geological Survey, Branch of Information Services, Denver, Colorado, USA.

Pachepsky, Y.A., A.M. Sadeghi, S.A. Bradford, D.R. Shelton, A.K. Guber, and T. Dao. 2006. Transport and fate of manure -borne pathogens: modeling perspective. Agr. Water Manage. 86:81-92.

Rohatgi, V. 1984. Statistical inference. 940 p. John Wiley \& Sons, New York, USA.

Shanks, O., C. Nietch, M. Simonich, M. Younger, D. Reynolds, and K. Field. 2006. Basin-wide analysis of the dynamics of fecal contamination and fecal source identification in Tillamook Bay, Oregon. Appl. Environ. Microbiol. 72:5537-5546.

Smith, S V., R.M. Chambers, and J.T. Hollibaugh. 1996. Dissolved and particulate nutrient transport through a coastal watershed-estuary system. J. Hydrol. 176:181203.

Solo-Gabriele, H.M., M.A. Wolfert, T.R. Desmarais, and C.J. Palmer. 2000. Sources of Escherichia coli in a coastal subtropical environment. Appl. Environ. Microbiol. 66:230-237.

Tian, Y.Q., P. Gong, J.D. Radke, and J. Scarborough. 2002. Spatial and temporal modeling of microbial contaminants on grazing farmlands. J. Environ. Qual. 31:860-869.

Troussellier, M., P. Got, M. Bouvy, M. M'Boup, R. Arfi, F. Lebihan, et al. 2004. Water quality and health status of the Senegal River estuary. Mar. Pollut. Bull. 48:852862.

Wheeler, A.L., P.G. Hartel, D.G. Godfrey, J.L. Hill, and W.I. Segars. 2002. Potential of Enterococcus faecalis as a human fecal indicator for microbial source tracking. J. Environ. Qual. 31:1286-1293. 